\title{
溶涬中の窒素定量法に関する二, 三の実験
}

\author{
木村 弘* 泉辰昌* 壇 武弘** \\ 下尾聰夫* 测合距雄*
}

Hiroshi Kimura, Tatsumasa Izumi, Takehiro Dan, Toshio Shimoo and Masao Kawai: Determination of Nitrogen in Molten Slags. The modified "Dumas-Pregel method" for the determination of total nitrogen in slags, which is a simple and rapid method compared to the ordinary one, is recommended in this paper.

The nitrogen contents in the carbon-saturated synthetic slags of $\mathrm{CaO}-\mathrm{Al}_{2} \mathrm{O}_{3}, \mathrm{CaO}-\mathrm{SlO}_{2}$ and $\mathrm{CaO}-$ $\mathrm{SiO}_{2}-\mathrm{Al}_{2} \mathrm{O}_{3}$ systems were determined by the "Combustion method" and the "Kjeldahl method"

The results obtained are as follows:

(1) By the addition of an oxidizer to slag sample, the total nitrogen can be completely extracted regardless of the bonding states of nitrogen in slags.

(2) The oxidizer consisting mainly of $\mathrm{CuO}$ is most suitable for the proposed method.

(Recerved January 6, 1970)

\section{I. 緒言}

溶涬中の空菜の笔動を研究するためには，その絬合形態 に応じたそれぞれの窒素量および全空素量を知る必要があ る、スラグ中の窒素の定量には，従来は一般に鋼中窒素の 定量法として確立されたケルダール法が多く適用されてい るが，全案素量を定量する場合は酸に溶解困難な窒化物な ぞの残渣処理を必要とするため長時閌を要する。金属空化 物中の窒素の定量法として，前田 ${ }^{(1)}$ ，士层(2) は燃烓法を採 用して良败な絬果が得られることを竍告している。秃れ われは有機化学の分野で適用されている空等媺量定量法 (Dumas \& Pregl 法) (3) を参考化して，然烧江によるスラ グ中の全窒素の定是法について検討し，空素含有最範囲 0.05〜10\%のスラグ試料汇適用し得る装置を製作し好結 果を得たので報告する。

\section{II. 置}

定量装置の概略はFig.1亿示す．主要部分はキャリヤー ガス $\left(\mathrm{CO}_{2}\right)$ 発生装置，燃焼炉，酸化銅一還元銅炉敊上び窒素 計より成っている。

\section{1. キャリヤーガス発生装置}

キャリヤーカスとしての $\mathrm{CO}_{2}$ 発生裴策はキップ発生器 (発生室内容䅡 $1 \mathrm{~L}$ (a) 战よび $3 \mathrm{~L}$ (b))を直列 2 連に連結して 使用し，主発生器 (b) 内の塩酸が空気中より窒素を吸収す ることを防いだ．塩酸は $\mathrm{CO}_{2}$ を吹込んで吸蔵されている

* 大阪府立大学工学部 (College of Engineering, University of Osaka Prefecture, Sakai)

** 大阪府立大学, 現在：金属材料技術研究所 (University of Osaka Prefecture, Sakai.Prcent address: National Research Institute for Metals, Tokyo)

(1) 前田：鉄之鋼, $21(1935), 22$.

(2) 土屋：分析化学, $7(1958), 12$.

（3）日本化学会編：有機化合物の分析，实検化学講夾 16, 丸善, (1958).

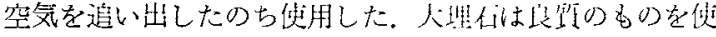

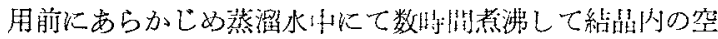
気を水で置換したのち使用した。このようにして $99.99 \%$ $\mathrm{CO}_{2}$ 程度のガスが敞将得られた。

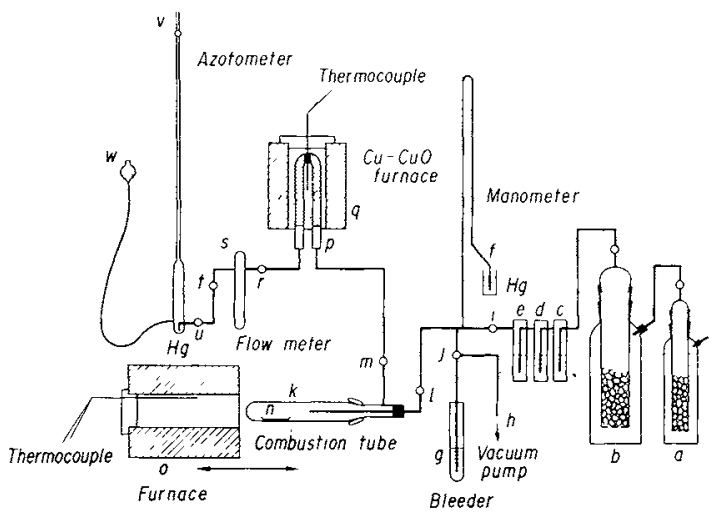

Fig.1 Schematic diagram of analytical apparatus

\section{2. ガス清浄装置}

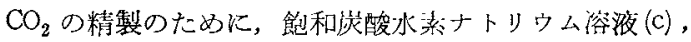

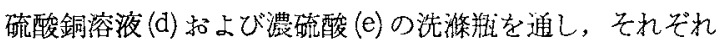
塩酸蒸気，有機物拈よび水分を除去した。

\section{3. 燃焼管および燃焼炻}

然煍管 $(\mathrm{k})$ は内径 $35 \mathrm{~mm}$ ，垃さ $250 \mathrm{~mm}$ の小透明们笑製 で,この加熱には可動式シリコニット佲（）を使用し，最

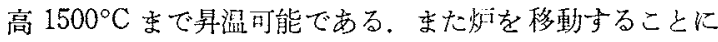

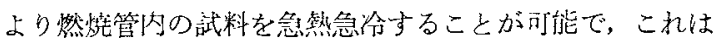
多数の試料を連続して分析する淕命に所要将阔の短繀に役 立った。

\section{4. 酸化銅-還元銅炻}

不透明不英製U字管（p）の中央部に鈳絧を装人して2空 に分け。一方に酸化銅（メルク社製線状），他方に還元銅(前 
記酸化銅を水素透元したもの）を充填し，加熱は二クロム 電気抵抗炉 (q)を使用し，自動調節温度計により $550^{\circ} \mathrm{C} に$ 保持した.

\section{5. ガス流量計}

窒素計の前に浅けた流量計（s）は抽出に要した全キャリ ヤーガス量を测定し，そのブランク值より空素計の読みを 補正するためのものである.

\section{6. 窒 素 計}

Schiff 氏窒素計 (v)を邀用し，ビューレット部の容量は $10 \mathrm{cc}$ で, 1 目盛は $0.01 \mathrm{cc}$ とした。吸収液は $50 \% \mathrm{KOH}$ 用いた。

\section{7. 真空装置}

回転式真空ポンプ (h) により分析系内の排気ができるよ うにした。 これは燃焼管および酸化銅－還元銅炬内の吸着 ガスを除去するために設けられたものであるが，それに付 属す引生力語 (f) は分析系の気密保持確認のテスターの役 目多ささせた。

\section{III. 基 礎 実 験}

\section{1. 酸化銅-還元銅炉}

試料に助然剂を加えて燃焼させた場合, $\mathrm{N}_{2}$ のほかに $\mathrm{H}_{2}$, $\mathrm{CO}, \mathrm{NO}, \mathrm{N}_{2} \mathrm{O}, \mathrm{NO}_{2}, \mathrm{O}_{2}$ などのガスが若干生成する恐れが あるので, 還元剤あるいは酸化剂を用いて窒素酸化物は窒 素に，その他のガスは $\mathrm{KOH}$ 溶液に吸収し得る形，すなわ ち $\mathrm{CO}_{2}$ あるいは $\mathrm{H}_{2} \mathrm{O}$ にしなければならない, 酸化剂, 還 元剂としてそれぞれ酸化銅，還元銅を $550^{\circ} \mathrm{C}$ に加熱して 使用した場合, Table 1 に示す熱力学的数値からわかるよ 万に前述の条件は十分保証される。種々の窒素含有量の試 料について, 燃焼炬の温度を $1300^{\circ} \mathrm{C}$ とし, キャリヤーガ スを流量 $80 \mathrm{cc} / \mathrm{min}$ で流した場合, 酸化銅一還元銅炉通過 後のガスをガスクロマトグラフィーによって調查した結果 $\mathrm{N}_{2}, \mathrm{CO}_{2}$ 以外のガスは検出されなかった.

Table 1 Free energy $(\Delta G)$ and equilibrium pressure concerned with reaction between gas and $\mathrm{Cu}, \mathrm{CuO}$ at $550^{\circ} \mathrm{C}^{(4)}$

\begin{tabular}{|c|c|c|c|}
\hline & $R$ & $\begin{array}{c}\Delta G \\
(\mathrm{kcal})\end{array}$ & Equilibrium pressure \\
\hline $\begin{array}{l}\mathrm{H}_{2} \\
\mathrm{H}_{2} \\
\mathrm{H}_{2} \\
\mathrm{CO} \\
\mathrm{CO} \\
\mathrm{CO} \\
2 \mathrm{NO} \\
\mathrm{N}_{2} \mathrm{O} \\
2 \mathrm{NO}_{2}\end{array}$ & $\begin{array}{l}+\mathrm{Cu}_{2} \mathrm{O}=\mathrm{H}_{2} \mathrm{O}+2 \mathrm{Cu} \\
+\mathrm{CuO}=\mathrm{H}_{2} \mathrm{O}+\mathrm{Cu} \\
+2 \mathrm{CuO}=\mathrm{H}_{2} \mathrm{O}+\mathrm{Cu}_{2} \mathrm{O} \\
+\mathrm{Cu}_{2} \mathrm{O}=\mathrm{CO}_{2}+2 \mathrm{Cu} \\
+\mathrm{CuO}=\mathrm{CO}_{2}+\mathrm{Cu} \\
+2 \mathrm{CuO}=\mathrm{CO}_{2}+\mathrm{Cu}_{2} \mathrm{O} \\
+4 \mathrm{Cu}=\mathrm{N}_{2}+2 \mathrm{Cu}_{2} \mathrm{O} \\
+2 \mathrm{Cu}=\mathrm{N}_{2}+\mathrm{Cu}_{2} \mathrm{O} \\
+8 \mathrm{Cu}=\mathrm{N}_{2}+\mathrm{Cu}_{2} \mathrm{O} \\
+4 \mathrm{Cu}=2 \mathrm{Cu}_{2} \mathrm{O} \\
+2 \mathrm{Cu}_{2} \mathrm{O}=4 \mathrm{CuO}\end{array}$ & $\begin{array}{l}-19.55 \\
-30.50 \\
-40.22 \\
-23.11 \\
-32.86 \\
-42.61 \\
-94.36 \\
-61.03 \\
-66.00 \\
-54.60 \\
-15.00\end{array}$ & 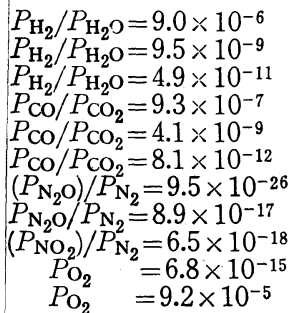 \\
\hline
\end{tabular}

(4) Table of Chemical Kinetics Homogeneous Reactions, Nat.Bur.Stand.U.S.A. (1951).

\section{2. 助 燃 剂}

助然剂の条件として，(i) スラグと溶け合い反忘しやす いこと，(ii) 分析温度に近い温度で解離し酸素を供給する こと，(iii）燃焼残留物を完全に溶解し適度の粘性を与え ること, (iv) ブランク值が小さいこと，(v) 取扱いやすい ことなどが考えられる. 助然剤として単味の $\mathrm{Na}_{2} \mathrm{O}_{2}, \mathrm{PbO}$, $\mathrm{CuO}$ 抢よび $\mathrm{PbCrO}_{4}$ について検討した結果, 単味の助然剤 としては $\mathrm{CuO}$ が上記条件を最もよく満たすすのであった。 しかし試料のスラグ組成により融点および粘性が異なるた めこれらを適度に調整する必要がある。すなわち $\mathrm{CuO}$ 単 味の助然剤を使用した場合, 融点が高いため燃焼不完全の 場合あるいはスラグ組成によっては粘性が小さすぎて然焼 ボートより溢出する場合がある。このような場合は，それ ぞれ $\mathrm{Na}_{2} \mathrm{CO}_{3}$ あるいは $\mathrm{CaO}$ を適量加えた混合助燃剂を使用 して好結果を得た。一例として $\mathrm{CaO}-\mathrm{Al}_{2} \mathrm{O}_{3}-\mathrm{SiO}_{2}$ 系合成ス ラグの定量の場合に使用した混合助然剤は $\mathrm{CuO}: \mathrm{Na}_{2} \mathrm{CO}_{3}$ $=3: 1$ (重量比)であり, 分析温度 $1300^{\circ} \mathrm{C}$ に护けるこの助 然剤とブランク值との間には Fig. 2 に示すよ 5 に直線関係 が成立した：

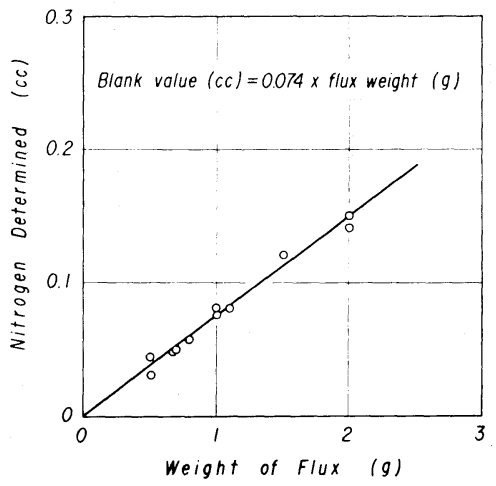

Fig.2 Blank value of nitrogen from flux

\section{3. 分析温度}

分析温度の決定のためには, 窒素含有量既知の標準試料 を定量することにより検討することが望ましいが，スラグ の場合適当な標準試料が得られないので本研究では含窒合 成スラグを溶製して試料とし，分析温度を種々変えて窒素 抽出率が一定になる温度を完全に抽出される分析温度とし た.

$\mathrm{CaO}-\mathrm{Al}_{2} \mathrm{O}_{3}$ 系および $\mathrm{CaO}-\mathrm{SiO}_{2}$ 系合成スラグを $1000^{\circ}$ 〜 $1350^{\circ} \mathrm{C}$ の温度範囲で分析した結果を Fig.3 に示す. 1200 ${ }^{\circ} \mathrm{C}$ 以上で抽出窒素量はほぼ一定となり, 燃焼残留物は完 全に溶融状態で得られたので以後の分析温度は $1300^{\circ} \mathrm{C}$ 採用することとした，試薬特級 $\mathrm{KCN}$ を標準試料とし，助 然剂 ( $\left.\mathrm{CuO}: \mathrm{Na}_{2} \mathrm{CO}_{3}=3: 1\right)$ を加兄て $\mathrm{KCN}$ 中の窒素を分析 温度 $1300^{\circ} \mathrm{C}$ で定量した結果を Table 2 に示す。その結果 は化学量論的な値と非常によく一致した.このことより $\mathrm{KCN}$ 中の窒素は上記分析条件によって $100 \%$ 抽出できる と考えられる. 


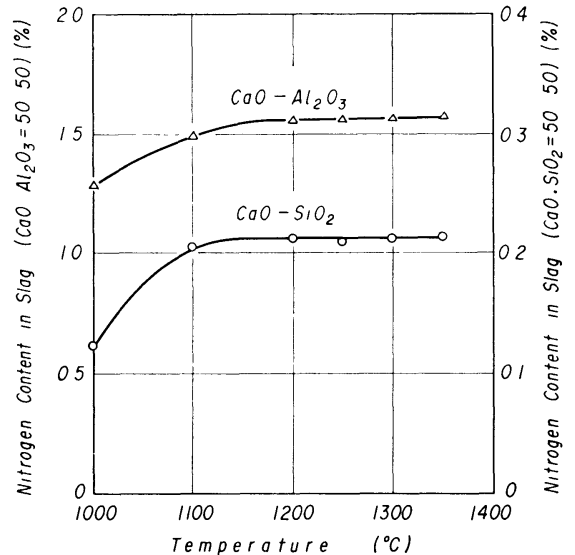

Fig.3 Effect of heating temperature of sample

Table 2 Nitrogen content in $\mathrm{KCN}$

\begin{tabular}{|c|c|c|c|c|c|}
\hline \multirow{2}{*}{$\begin{array}{l}\text { Weight of } \\
\text { sample (g) }\end{array}$} & \multirow{2}{*}{$\begin{array}{l}\text { Uncorrected } \\
\text { value }(\mathrm{cc})\end{array}$} & \multirow{2}{*}{$\begin{array}{c}\text { Blank } \\
\text { value }(\mathrm{cc})\end{array}$} & \multicolumn{2}{|c|}{$\begin{array}{l}\text { Corrected } \\
\text { value }\end{array}$} & \multirow{2}{*}{$\begin{array}{l}\text { Devi- } \\
\text { ation } \\
(\%)\end{array}$} \\
\hline & & & (cc) & $(\%)$ & \\
\hline $\begin{array}{l}0.0251 \\
0.0257 \\
0.0299 \\
0.0304 \\
0.0307 \\
0.0312 \\
0.0345 \\
0.0348\end{array}$ & $\begin{array}{l}4.98 \\
4.98 \\
5.88 \\
5.88 \\
5.98 \\
6.08 \\
6.84 \\
6.69\end{array}$ & $\begin{array}{l}0.10 \\
0.10 \\
0.11 \\
0.10 \\
0.10 \\
0.10 \\
0.11 \\
0.10\end{array}$ & $\begin{array}{l}4.88 \\
4.88 \\
5.77 \\
5.78 \\
5.88 \\
5.98 \\
6.73 \\
6.59\end{array}$ & $\begin{array}{l}21.6 \\
21.5 \\
21.6 \\
21.2 \\
21.5 \\
21.5 \\
21.8 \\
21.5\end{array}$ & $\begin{array}{r}+0.5 \\
0.0 \\
+0.5 \\
-1.4 \\
0.0 \\
0.0 \\
+1.4 \\
0.0\end{array}$ \\
\hline
\end{tabular}

* Theoretical nitrogen content in $\mathrm{KCN}=21.5 \%$

\section{4. 試料採取}

石英管で吸上げ水冷する方法を試みたが，スラグが石英 管壁と若干反応する恐れがあり，好ましくないので，溶融 スラグをステンレス棒に付着させ空冷する方法をとった。

これをめのう乳鉢にて粉砕し分析試料とした。この試料の 保存期間の分析值におよぼす影響を調查するため，次の実 験を行なった。 $\mathrm{CaO}-\mathrm{Al}_{2} \mathrm{O}_{3}$ 系, $\mathrm{CaO}-\mathrm{SiO}_{2}$ 系拉よび $\mathrm{CaO}$ $\mathrm{SiO}_{2}-\mathrm{Al}_{2} \mathrm{O}_{3}$ 系合成スラグを $\mathrm{H}_{2} \mathrm{SO}_{4}$ デシケーター中に保存し て経时変化を測定した結果は Table 3 に示すように特に 定量値の变化は認められなかった。

Table 3 Effect of time on nitrogen content $(\%)$ of slag held in a desicator $\left(\mathrm{H}_{2} \mathrm{SO}_{4}\right)$

\begin{tabular}{c|c|c|c}
\hline $\begin{array}{c}\text { Time } \\
\text { (day) }\end{array}$ & $\begin{array}{c}\mathrm{CaO}: \mathrm{Al}_{2} \mathrm{O}_{3} \\
=50: 50\end{array}$ & $\begin{array}{c}\mathrm{CaO}: \mathrm{SiO}_{2} \\
=50: 50\end{array}$ & $\begin{array}{c}\mathrm{CaO}: \mathrm{SiO}_{2}: \mathrm{Al}_{2} \mathrm{O}_{3} \\
=44: 44: 12\end{array}$ \\
\hline 1 & $1.56(\%)$ & $0.575(\%)$ & $0.200(\%)$ \\
2 & 1.57 & 0.578 & 0.201 \\
3 & $\overline{-}$ & 0.579 & 0.208 \\
4 & 1.55 & $\overline{-}$ & 0.206 \\
5 & 1.56 & 0.582 & 0.197 \\
6 & 1.57 & 0.579 & 0.203 \\
7 & & & \\
\hline
\end{tabular}

\section{IV. 分 析 操 作}

本燃焼法によるスラグ中の全窒素の定量分析操作は次の ように行なら。

燃焼炉 (o) 特よび酸化銅一還元銅炉 (q)をとれぞれ $1300^{\circ} \mathrm{C}$ 抢よび $550^{\circ} \mathrm{C}$ 亿䒜温する。装置全系をキャリヤーガス $\left(\mathrm{CO}_{2}\right)$ で置換する.この際ガスはコック (t)より排出させ, 完全に置換したことを窒素計 (v)により確認する，そして コック (i) (1) (m) 怙よび (t)を閉じる。抽出ガス量が $1 \mathrm{cc}$ 以 上になるよう科量した試料に適量の助然剤を混合して磁性 燃焼ボートに入れ，これを燃焼管 $(\mathrm{k})$ に装入する。燃焼管 を分析系に装着し、コック(j)括よび (1) を開き，真空ポン プを作動して然焼管内を排気する，次にコック(j)を閉じ， コック (i)を開いてキャリヤーガスを燃燒管内に導入する. 上の排気扣よびキャリヤーガス導入の操作を $2 \sim 3$ 回繰返 し，然焼管内の空気を完全にキャリヤーガスで置換する.

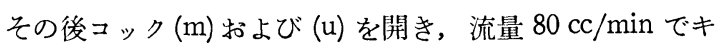
ヤリヤーガスを流す．窒素計 (v)によりキ+リヤーガスの ブランク值を測定する.コック (i) 括よび (1)を閉じ, あ らかじめ昇温してある燃焼炉 $(0)$ を移動して燃焼管 $(\mathrm{k})$ を $1300^{\circ} \mathrm{C}$ まで昇温する。 この温度に約 $5 \mathrm{~min}$ 保持し, 試料 と助然剤を反応させる. 次にコック(i)括よび(1)を開き， 流量 $80 \mathrm{cc} / \mathrm{min}$ でキ+リヤーガスを約 $5 \mathrm{~min}$ 流す. 燃焼炉 を移動し，燃焼管を放冷しながらキャリヤーガスをさらに 5 10 min 流し, 反応生成ガスを酸化銅 - 還元銅炉を経て 完全に窒素計に導く、窒素計の気泡吸収状態の観察によ り，系内が完全にキャリャーガスで置換されたことを確認 したのち、コック(u)を閉じ数分間放置して窒素計内の気 泡を完全に浮上させ，残留ガス量を読みとる．この值から キャリヤーガス括よび助然剤のブランク值を控除し，さら に $50 \% \mathrm{KOH}$ 溶液の蒸気圧を減じたものを真の窒素量 $V$ とする.

窒素含有量 $\mathrm{N} \%=100 \mathrm{~V} \cdot f / W$

ただし $V=t^{\circ} \mathrm{C}, \mathrm{Pmm} \mathrm{Hg}$ に甜ける窒素量 (cc)

$f=t^{\circ} \mathrm{C}, \mathrm{Pmm} \mathrm{Hg}$ に括ける窒素 $1 \mathrm{cc}$ の重量 $(\mathrm{mg})$ $W=$ 試料重量 $(\mathrm{mg})$

以上の分析所要時間は約 $30 \mathrm{~min}$ である.

\section{V. ケルダール法と燃焼法との比較}

スラグ中の全窒素の定量にヶルダール法を適用する場 合, 酸可溶空素は比較的簡単に定量することができるが， 酸難容性の窒化物などが生成している場合には残渣処理が 必要となり，操作は繁雑となりかつ長時間を要する。また スラグ中の窒素の存在形態は未だ明らかでないため, ケル ダール法の適用には種々の問題点が残る。しかるに，然焼 法は助然剤が有効に反応すれば，スラグ中の空素の存在形 態に関係なく全窒素を抽出することができる。

著者らは燃焼法とケルダール法とを併用して同一試料の 
定量を行ならならば，燃焼法の信頼度の検討となると同時 に，スラグ中の窒素の存在形態解明の一助ともなるものと 考穴，合成スラグについて二，三の実験を行なった。

\section{1. 実験方法}

合成スラグの原料は, $\mathrm{CaO}$ 成分として試薬特級 $\mathrm{CaCO}_{3}$ を 焙焼したもの, $\mathrm{Al}_{2} \mathrm{O}_{3}$ 成分として電融アルミナ, $\mathrm{SiO}_{2}$ 成分 としては石英管を粉砕して使用した.

これらを配合して黒鉛ルッボに入れ，高周波誘導炉によ って $\mathrm{Ar}$ 雲囲気中で $1600^{\circ} \mathrm{C}$ で溶製し，炭素飽和の 2 元拉 よび 3 元系の合成スラグを得た.さらにこれをめのう乳鉢 にて粉砕し，黒鉛ルツボに入れて特殊タンマン炉にて溶解 し， $\mathrm{N}_{2}$ を炭素管を通じてスラグ中に吹き込み，所要の組 成の含窒炭素飽和スラグを溶製した。これらの試料につき ケルダール法による酸可溶窒素と燃焼法による全窒素とを 定量し比較検討した.

\section{2. 実験結果および考察}

含窒炭素飽和スラグを燃焼法により定量した結果の一例 を Table 4 に示す.

$\mathrm{CaO}: \mathrm{SiO}_{2}=50: 50$ 炭素飽和合成スラグについてケルダ ール法拐よび燃焼法により定量した結果の比較は Fig.4に 示すよ 5 に窒素量 $0.5 \%$ 以下の範囲で可成り良く一致して いる.

Table 4 Example of total nitrogen determined by combustion method

\begin{tabular}{c|c|c|c|c}
\hline \multirow{2}{*}{ Sample } & \multicolumn{3}{|c|}{ Analytical No. } & Average \\
& 1 & 2 & 3 & value \\
\hline $\begin{array}{c}\mathrm{CaO}: \mathrm{Al}_{2} \mathrm{O}_{3} \\
=50: 50\end{array}$ & $0.586(\%)$ & $0.591(\%)$ & $0.587(\%)$ & $0.588(\%)$ \\
\hline $\begin{array}{c}\mathrm{CaO}: \mathrm{Al}_{2} \mathrm{O}_{3} \\
=50: 50\end{array}$ & 1.67 & 1.66 & 1.67 & 1.67 \\
$\begin{array}{c}\mathrm{CaO}: \mathrm{SiO}_{2} \\
=50: 50\end{array}$ & 0.251 & 0.252 & 0.251 & 0.251 \\
\hline $\begin{array}{c}\mathrm{CaO}: \mathrm{SiO}_{2}: \\
\mathrm{Al}_{2} \mathrm{O}_{3}=44: 44: 12\end{array}$ & 0.122 & 0.121 & 0.120 & 0.121 \\
\hline
\end{tabular}

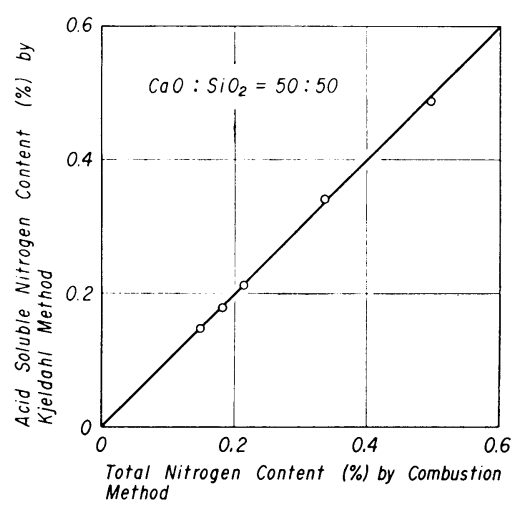

Fig. 4 Comparison of result of nitrogen by combustion method and Kjeldahl method
$\mathrm{CaO}: \mathrm{Al}_{2} \mathrm{O}_{3}=50: 50$ 炭素飽和合成スラグの場合は, $\mathrm{CaO}-\mathrm{SiO}_{2}$ 系より高窒素濃度の陚料を溶製することができ たが，その定量結果は Fig.5に示すように,ケルダール法 による酸可溶窒素の定量值は窒素濃度の増大と共に, 燃焼 法による全窒素定量值に対して負に偏倚している，酸難溶 残椬が特に認められないにもかかわらず，このよ5な低值 を示す原因として $\mathrm{CN}^{-}$の存在が十分考えられるので, 硝 酸銀滴定法により $\mathrm{CN}^{-}$の検出を試み, その存在を確認した のでこれを定量し， $\mathrm{CN}^{-}$とての $\mathrm{N}$ を酸可溶窒素に加算し て補正したところ燃焼法による全窒素量とほぼ一致した。

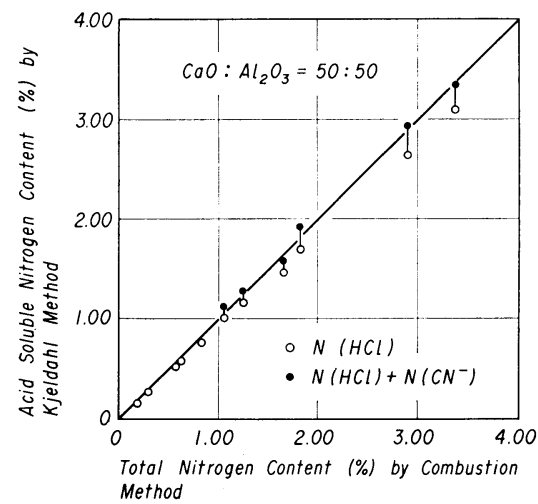

Fig. 5 Comparison of result of nitrogen by combustion method and Kjeldahl method

$\mathrm{CaO}: \mathrm{SiO}_{2}: \mathrm{Al}_{2} \mathrm{O}_{3}=44: 44: 12$ 炭素飽和合成スラグの両 法による定量結果の比較を Fig.6 に示す.この組成のスラ グは $\mathrm{CaO}-\mathrm{SiO}_{2}$ 系スラグと同様に比較的低窒素濃度で飽和 するので高窒素濃度範囲の定量值の比較はできなかった が，0.4\% 以下の低窒素濃度範囲では両法の定量 結果はよ く一致している.

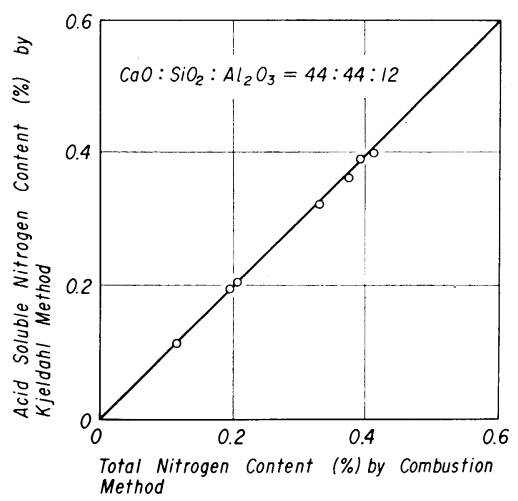

Fig. 6 Comparison of result of nitrogen by combustion method and Kjeldahl method

\section{VI. 結 言}

（1）適当な助然剤を選択適用すれば，本燃焼法によりス ラグ中の窒素の存在形態に関係なく, その含有全窒素を定 量することができる。

（2）スラグ中の全窒素量は燃焼法によると比較的短時間 で定量できる。

（3）助然剤は $\mathrm{CuO}$ を基剤としたものか適当である. 